126 Наукові записки ХНПУ ім. Г.С. Сковороди. Літературознавство, 2020, вип. 2(96)

УДК 82.091.161.2Самчук

Оксана Румянцева-Лахтіна

\title{
ІНТЕРТЕКСТУАЛЬНИЙ КОНТЕКСТ СИМВОЛІКИ СІМЕЙНИХ РОМАНІВ УЛАСА САМЧУКА КРІЗЬ ПРИЗМУ ФІЛОСОФСЬКОЇ ЧАСОПРОСТОРОВОЇ ВЕРТИКАЛІ
}

\section{Ветуп}

Еволюція сімейного роману в українській літературі у XX столітті потребує аналізу його жанрових модифікацій та виокремлення жанрових домінант. Усі поетичні засоби, які входять до складу цього жанру, тією чи тією мірою беруть участь у створенні художнього образу дійсності. Жанроутворювальні елементи несуть структурну та організаційну функцію і дозволяють визначити такі поетичні засоби, як часові площини, філософський аспект, соціальні проблеми, що виступають неначе «каркасом» формування певного жанру.

Дослідження сімейних романів української літератури здійснюється в більшості випадків на матеріалі творів XX і XXI століття, бо розквіт жанру сімейного роману в українській літературі досягає апогею лише в цей час (В. Шевчук «Тіні зникомі», В. Лис «Століття Якова» $\mathrm{i}$ «Соло для Соломії», М. Матіос «Солодка Даруся», О. Забужко «Музей покинутих секретів» та інші). Важливими у розвитку цього жанру є трансформації сімейного роману, що можна спостерігати на прикладі творів початку й середини XX століття (романи I. Франка «Петрій і Довбущуки», У. Самчука «Волинь» i «Марія»), коли субжанрами (модифікаціями) сімейного роману стають сімейна сага й сімейна хроніка.

Науковці визначають ряд ключових ознак сімейної саги: епопейність і поліфонічний динамізм зображувальних історичних подій, розширення меж діяльності персонажів, уведення тематики генеалогії (Джіоєва, 2019). Принципово відрізняється сімейна сага від сімейного роману розширенням оповіді, епохальним хронотопом. Сімейна хроніка характеризується осмисленням долі приватної

(C) Оксана Румянцева-Лахтіна, 2020

http://dx.doi.org/10.34142/2312-1076.2020.2.96.08 
особи, причому орієнтирами на життєвому шляху героя стають, як правило, не історичні чи соціальні події, а моральність роду, його духовні цінності (Джіоєва, 2019).

Зразком української сімейної саги вважають роман-трилогію Уласа Самчука «Волинь». В. Шевчук визначає роман як «волинську сагу», бо не можливо не помітити певну спорідненість Самчукової «Волині» 3 давньоісландським епосом, цей роман суголосний із родинними сагами, що мали вагомий вплив на європейську літературу кінця XIX - середини XX ст. (Р. Роллан, К. Гамсун, В. Реймонт, Т. Манн, Дж. Голсуорсі). (Шевчук, 1999: 3).

В Україні ім'я письменника, його творчість були надовго, майже на півстоліття, забуті. Твори його тривалий час в Україні не видавалися, а ті, що були опубліковані, читалися й трактувалися порізному. Улас Самчук - обдарований прозаїк та публіцист, творчість якого привертала увагу літературознавців як в Україні, так і за їі межами, але деякі розвідки мають надто узагальнений характер або зосереджуються на соціальній чи національній проблематиці.

Однак з огляду на великий обсяг творчого доробку письменника, на ознайомлювальний та описовий характер багатьох досліджень, на зосередженість науковців переважно на ідеологічно-змістових особливостях творів У. Самчука, можна говорити про те, що в літературознавчих студіях до сьогодні не досліджені окремі аспекти (насамперед - жанрово-стильові особливості, поетика, символіка сімейних романів «Волинь» і «Марія»), що зумовлює необхідність поглибленого й системного вивчення особливостей вищезазначеного жанру на прикладі художньої творчості письменника.

Дослідження художньої прози У. Самчука стало об’єктом вивчення сучасних науковців - С. Бородіци, І. Бурлакової, М. Гона, М. Жулинського, Ю. Мариненка, С. Пінчука, Я. Поліщука та інших. Світоглядну та художньо-естетичну парадигму творів Уласа Самчука за принципом герменевтичної деканонізації (текст як першооснова аналізу поетики вираження авторської свідомості Самчука й проявленого в ньому «життєвого світу») досліджували науковці 
О. Веретюк, М. Гон, Р. Гром'як, Н. Лисенко, Р. Мовчан, С. Пінчук, Я. Поліщук, М. Ткачук.

Мета статті - виявити жанрово-стильові домінанти сімейної саги «Волинь» і сімейної хроніки «Марія» У. Самчука як субжанрів сімейного роману в українській літературі початку $\mathrm{XX}$ століття, дослідити образність, поетику та сакральні образи-символи, які $\epsilon$ каталізаторами зображувальної епохи, з'ясувати особливості символіки онтологічних, антропологічних та профанних «кодів» сімейних романів крізь призму інтертекстуальності та філософського й соціального розуміння часопросторової вертикалі художнього твору. У статті ми спробуємо показати, що сімейні романи «Волинь» i «Марія» У. Самчука $\epsilon$ варіаціями реалізації універсальної моделі розповіді про сакральні духовні цінності, про родовід, про добро і зло.

На наш погляд, слід розглядати сімейні романи У. Самчука крізь призму інтертекстуальності, а саме, через інтерпретацію образівсимволів, що репрезентовані письменником у вищезазначених творах.

\section{Методологія}

Великий внесок у розвиток поняття інтертекстуальності й інтертексту було зроблено французьким літературознавцем, структуралістом і постструктуралістом Роланом Бартом. Учений запропонував теоретичне обгрунтування понять «твір» та «текст», наголосивши, що саме «текст» повинен стати об’єктом уваги літературознавця, і висунувши принцип «читання - письма». Згідно з Р. Бартом основою тексту є «не його внутрішня, закрита структура, яка піддається докладному вивченню, а його вихід в інші тексти, інші коди, інші знаки; текст існує лише у силу міжтекстових відносин, в силу інтертекстуальності» (Барт, 1989: 428). Під час читання тексту, аналізуючи його структуру, тобто у процесі «означування» (Р. Барт), віднаходження кодів $€$ «відправною точкою/точкою відліку “вже читаного”, як трамплін інтертекстуальності» (Барт, 1989: 459).

Термін «інтертекстуальність» у літературознавстві вперше пролунав від Юлії Кристевої, і восени 1966 року в доповіді «Бахтін, 
слово, діалог і роман» його було озвучено вперше (Кристева, 2000). Особливу увагу приділено вченою аналізу роботи Бахтіна «Проблема змісту, матеріалу і форми в словесній художній творчості» (1924), де було сформульовано ідею художнього діалогу культур, яка лежить в основі поняття «інтертекстуальність», хоча сам термін Бахтіним не вживається: «Будь-який текст - це всотування і трансформація якого-небудь іншого тексту» (Кристева, 2000). Саме М.М. Бахтін, на думку вченої, підкреслював, що діалогічний характер слова не обмежений теперішнім часом, що згодом обов'язково враховується в практиці інтертекстуального аналізу.

Дослідник І.П. Ільїн зауважує, що світ із погляду інтертекстуальності постає як величезний текст, у якому все колись було вже сказано, а нове є можливим тільки за принципом калейдоскопу, коли змішування певних елементів дає нові комбінації (Ільїн, 1999).

Ж. Женнет у своїх «Палімпсестах. Література в другому ступені» дав типологічну класифікацію видів інтертекстуальності, виділивши інтертекстуальність як цитату, алюзію, плагіат; паратекстуальність, тобто коментар у тексті, що включає передмову, післямову, епіграф; метатекстуальність, коли в одному тексті існують коментарі стосовно іншого тексту; гіпертектуальність, що характеризується відносинами між текстом В із раніше створеним текстом А, та архітекстуальність, яка виступає як сукупність правил, згідно з якими було створено текст (Женетт, 1998: 207).

\section{Результати і дискусія}

Вершиною творчості письменника, художнім літописом української історії ХX століття є роман-трилогія «Волинь» Уласа Самчука - «Куди тече та річка», «Війна і революція», «Батько і син». Селянська сімейна сага Уласа Самчука - це широке епічне полотно про життя волинян у першій третині XX століття, у якому відтворено духовні аспекти та історію родини Довбенків у зображенні минулого, сьогодення та майбутнього всієї родини. Роман є своєрідним гімном 
Волині, що оспівує селянську працю, любов до землі, сімейні цінності української нації.

Саме «волинською сагою» У. Самчук заявив про себе як майстер розлогого епічного мислення, що володіє талантом бачити не лише долю окремо взятої людської особистості, а й цілого народу; як філософ, котрий шукає відповіді на питання історичного призначення українського народу, репрезентує найважливіші духовні цінності, що визначають глибинний рівень ментальності нації й підвалини гуманізму. У полі зору митця - становлення національної свідомості волинського селянина у вирі бурхливих подій Першої світової війни, революції, проголошення УНР, польської окупації. Герої сімейної саги «Волинь», покоління Довбенків, увиразнюють життєву позицію пересічного українця: ставлення людини до землі, праці - найважливіші критерії оцінки людини.

Засвоївши і трансформувавши досвід європейської літератури, зокрема розвиток характерів і подій у великих формах Ромена Роллана, Джона Голсуорсі, Мартена дю Гара, Улас Самчук розвиває жанр у дусі національних традицій, створюючи сімейні романи на тлі складних історичних подій на зламі тисячоліть і складних обставин в українському суспільстві.

Спробуємо розшифрувати інтертекстуальні, «вічні» для українця, символи роману «Волинь», що в герменевтичному колі Самчукового світобачення зумовлені цілісним розумінням світу, пізнанням самого себе, історії роду та народу, розкрити ціннісні орієнтири персонажів, зображені письменником крізь призму часопросторової вертикалі.

Символіка - поняття загальнолюдське, але попри універсальність символьних кодів, має й національно-культурну специфіку, зумовлену низкою зовнішніх i внутрішніх факторів. Етимологічно слово

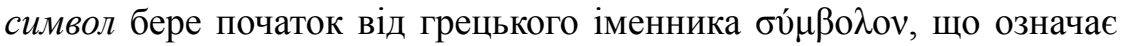
знак, прикмета. Таке тлумачення свідчить про те, що у свідомості людини навколишній світ сприймався не лише у видимих формах, але й порівнювався, уподібнювався певним явищам, предметам, які іiі оточували. Власне, у символі відображено певні уявлення, почуття, думки, ідеї народу. Символіка, як поняття етногенетичне, допомагає 
нам зрозуміти спосіб мислення нашої нації, моральні, духовні, етичні й естетичні ідеали. В. Кононенко, зокрема, підкреслює, що морально-етичні ідеали, передані через символи, часто набувають яскраво вираженого національного характеру, адже «саме в символах нерідко відбиваються народні традиції, звичаї, обряди, вірування тощо, а зрештою, і національні риси характеру, рівень національної свідомості. Словесна символіка народу виступає важливим чинником творення національно-культурної картини світу; навіть індивідуальні символи, характерні для художньотворчого осмислення дійсності, звичайно зумовлені особливостями національного мовного типу, мовної особистості» (Кононенко, 1991: 31).

3 давніх-давен 3 вертикаллю трьох світів (поняттями підземне низьке, високе - небесне, земне - людське, буденне) пов'язані вірування й сподівання. Часопросторова вертикаль художнього твору як вертикаль філософська й вертикаль трьох світів - небесного, земного іпідземного, є основою людських поривань і гріхів: вертикаль вгору пов’ язана з нескінченністю й необмеженістю, вертикаль вниз зі смертю плоті й муками. Земля ж - простір, де можуть жити й боротися істоти, що потрапляють як до небесного царства, так і до підземного (Копистянська, 2012: 115).

Філософія світобачення Уласа Самчука як відданого рідній землі українця органічно випливає 3 самого буття й відтворена в тексті сімейної саги «Волинь». На джерела формування світогляду та світовідтворення письменника впливають декілька чинників. Паростки свідомості передусім пов'язані 3 розумінням Роду як сакрального «центру» й архетипами Батька, Матері. Саме так зароджується автентичне світоуявлення. У мемуарах Улас Самчук згадував, що «раціонально заложений», батько заклав основи мислення, мати «мрійниця, неграмотний філософ серця. Безпосередній шматок чистої природи в дусі і тілі, що могла жити з ласки сонця і щедроти землі, як кожна ластівка» (Самчук, т.1: 304). 
Перша частина трилогії «Волинь», «Куди тече та річка», починається 3 ідилічної картини людської праці в колі родини: обробка землі, випікання хліба, випас худоби, що характерне для сагового хронотопу: «Батько корчує пні за лісом на вирубі - гейби не заважали на тому шматку такого дорогого поля» (Самчук, т. 1: 6). Початок тексту, його розгортання й кульмінація мають аксіологічне навантаження: батько корчує пні - мати пішла до млина - Василь корови пасе - «хіба та дітвора всидить вам вдома» - фіксує два орієнтири: йдеться про родинне коло і працю на землі. Реалістичну характеристику батька посилено міфологічноантропологічною: «Зросту Матвій великого... Постать його потужна, міцно збудована, «яких сьогодні вже немає». Робота в його руках горить. Ступить - земля гнеться. Ударить кулаком - довбні не треба. Дуб дубом мужик» (Самчук, т. 1: 18). Образ батька, Матвія Довбенка, родоначальника, постає у творі монументальним і непохитним. Він i сам наче дуб-велетень: «Здається, він далеко серед широкого поля вкопався в землю і головою торкається хмари» (Самчук, т. 1: 571).

Домінанти сенсу існування Матвія - рідний хутір (земля), у яку він неначе вростає корінням, його духовний простір - небо (Всесвіт), до якого він намагається доторкнутися. Людина, яка обробляє землю, одразу підноситься до неба, стає ближчою до Бога, бо, на думку М. Еліаде, небо символізує трансцендентність, міць і непохитність уже внаслідок свого місцезнаходження (Еліаде, 1999: 51). Так само грунтовно й монументально, як патріарх великої родини, Матвій Довбенко молиться. Батько молиться довго, широко і уважно хреститься. «Матвій говорив голосно з Богом! I тут любив ясність. Кожне слово вимовляв «трезво», повно. Не любив дрібних, звичайних молитов, любив псальми. У них говорилось до Бога гарною, вибраною мовою. Кожне слово, мов ядерне, пшеничне зерно» (Самчук, т. 1: 97). Саме так Матвій підноситься вверх, до неба, до Бога, хоча сам, як твердиня, стоїть на Землі. Ця вертикаль вгору пов'язується з нескінченністю, необмеженістю простору й часу, вічністю й безсмертям душі, наближенням до абсолюту. Як зазначив Ю. Лотман, вертикаль, спрямована вгору, - це розширення простору до безмежності, вертикаль, спрямована вниз, - звуження до кінцевої точки, 
де щезає простір: «...Рух можливий тільки вгорі, і опозиція «верх - низ» стає структурним інваріантом не тільки антитези «добро - зло», але й «рух - нерухомість» (Лотман, 1970: 97).

Так, у романі «Волинь» У. Самчука зображено чимало топосів, значення яких виходить за межі звичайного пейзажу, натомість вони наповнюються такими географічними деталями, які, символізуючись, перетворюються на своєрідний код твору. Особливою константою й онтологічним символом сімейної саги «Волинь» $\epsilon$ Земля, часопросторова вертикаль, яка може продовжуватись як вгору, так і вниз. Земля як координата Всесвіту лише відображає проміжне перебування, де зливаються буття людське й священне. Образсимвол Землі, родючого грунту, що є центральною, відправною точкою філософської часопросторової вертикалі, тієї Землі, звідки можна як піднестися як до неба, так і потрапити в підземелля, $є$ лейтмотивом побудови сюжетної ланки сімейної саги «Волинь». На думку Н. Плетенчук, дослідниці Самчукової творчості, у центрі цієї просторової моделі перебуває людина з релігійною свідомістю, яка є органічною частиною сакральної сфери. Це своєрідна топос-призма, крізь яку просвічується сенс людського буття (Плетенчук, 2011:168).

Образ Землі персоніфікований, вона органічно співіснує 3 людиною, яканемислитьсебебез праці: «Ситий, тяжкий дух зноситься над землею, ніздрі лоскоче сильний запах чорнозему, на чолі сходить піт і скапує по щоках до ріллі... Сонце - шалений і дикий огнепад, заливає лани, мужиків, птахів; земля, мов спрагла коханка, звабливо розпускає свої принади, що по них досхочу йдуть коханці і сиплють плодом, потом, молитвою! Роди велика, непорочна! Роди, прамати всіх родів!» (Самчук, т. 1: 251). Земля визначається як самоцінна, незалежна, постійно творча субстанція, а людина поєднується із нею передусім через дух, а потім - через матерію. Але гармонію ідеального простору ламає щоденна праця, що пригинає людину до землі й висмоктує з неї всі соки: «...проходить хребтом ціна землі своєї, лудяної сонцем, литої потом і болючої, як той хребет» (Самчук, т. 1: 251). Лише тяжкою працею можна заробити дорогоцінний хліб символ життя й існування людини на землі. 
Матвій Довбенко - хлібороб, людина, яка понад усе шанує працю й здатна вирощувати хліб - сакральний символ життя. Хліб як духовна таїна українського народу $є$ священним для кожного українця. Хлібна містерія пронизує усю палітру української духовної культури, усі нюанси сакрально-містичної обрядової традиції, увесь зміст законів української землі. Чудо «помноження хліба»-це найбільш дивовижне диво серед діянь Христа. Хліб - це даність від Бога, але заробити його можна лише копіткою працею. Матвій Довбенко каторжним трудом перемагає злидні; це людина, яка «ніколи не вста[є] пізніше за сонце» (Самчук, т. 1: 285), тому досконало розуміє філософію селянського буття. Він як патріарх $\mathrm{i}$ «сторож роду свого, як здоровий корінь своєї землі» (Самчук, т. 1: 285). Хліб народжений людською працею, а праця на землі визначає вищу сутність людини, іiі потяг до високого, небесного, духовного. Саме тому монументальний образ Матвія уособлює стійкість і спокій, а міфологічні просторові кореляції світу Рід-Бог-Родина вказують на його архетипність.

Концепція простору, за Н. Плетенчук, асоціюється 3 панспаціальністю, тобто 3 розширенням простору поля (грунту) надійним майбутнім добробуту власних дітей (Плетенчук, 2011: 165). У пошуках розширення свого горизонтального простору Матвій поривається шукати більшого: «...і приходить на думку Матвієві чи не кинути все то та йти у світ шукати для себе іншого місця. Землі треба! Простору! Росія ж велика - степи, далечі, землі широкі» (Самчук, т. 1: 571). Та пошуки власного грунту (по горизонталі) приводять до розширення просторових меж (по вертикалі): хоча Земля й позбавляє Матвія фізичного здоров'я, відчужує від родини, але важка праця народжує хазяїна, котрий має постійну жагу до труду. Селянин починає розуміти справжню сутність Землі національної, яку необхідно кожному українцю боронити під час хаосу війни й революції: «Не кидайте цих місць!.. Зубами гризіть, а бороніться, бо то ваші кубла, здобуті працею, потом, кривавою нелюдською працею. Це не гроші, не золото. Це ваша земля, яка ссала впродовж віків вашу і ваших дідів-прадідів 
кров. Діти ваші ростуть і вони мають замінити вас на цих місцях... Нас випхнуть на шлях $i$, мов ту черву, затопчуть у багно... Худобу хай женуть, а ви верніться!..» (Самчук, т. 1: 333).

Як зазначає Н. Плетенчук, для цілісного осмислення Самчукового світопереживання важливе заглиблення в метафізичну суть філософського образу землі (Плетенчук, 2011: 167). Поперемінне чергування наративних (теперішньої і минулої) перспектив дозволяє вловити дух «пересипання» і розмикання часу у філософському осмисленні вічного закону землі та Людини за плугом: «...і встають в уяві діти-велетні. Ідуть пралісами, рвуть столітні дуби, розчищають галявини, передають огневі хмиз і хащу: дикий звір чує запах поту людини за плугом і з диким жахом тікає у безвісті. Ішов плуг, ішов страшний мужик за плугом, розривав цілину, визволяв сковану силу землі, родив життя. Сливе побожно дивиться хлопець на ту ось, побіч, людину» (Самчук, т. 1: 253).

У Самчуковій «Волині» символом профанного світу родини Довбенків $є$ хутір. Хутір, сад, садиба, поле - це модель земного раю для старшого Довбенка. Образ хутора символізує потяг до волі. Недарма автор у «Волині» називає хутір Запоріжжя, натякаючи на самостійність із часів козацтва. Саме у просторі хутора народжується особистість хазяїна-власника. Матвій каже: «Не люблю того спільного. На своєму хоч стань, хоч сядь, хоч покотом. Я тут пан. Так. Кожний має право на кусник права в собі» (Самчук, т. 1: 257). Головна особливість сутності буття Довбенка-хуторянина це сакралізація профанного, радість пізнання сакрального через буденне. Побудувати дім, виплекати дерево (сад), виростити дітей це і $є$ універсальний закон життя.

Очевидно, що ідея наполегливої праці людини й турбота про екзистенцією була для У. Самчука фундаментальною. Вона закономірно породжується невловимістю сакрального, яке має лише апофатичні визначення, і здобувається лише поєднанням з усіма формами профанного світу.

Проте світ безкінечного й вічного стає можливим тільки завдяки тому, що людський дух обживає простори. Володько Довбенко, 
на відміну від батька, не вростає корінням у землю, не спішить iii обробляти. Він тягнеться до духовного, його манить небо. «Володько вертається самітньо зі школи, іде поза селом, городами, зрубами, лісом. Мліє земля... Володько задирає голову, і в ньому негайно прокидаються хижі бажання знов позмагатися 3 тими птахами. Але у нього під пахвою у торбині книга „Сеятель”, а на другому, угорському схилі долини поле засипане людьми... Володько прикладає до чола долоню, прижмурює очі і дивиться на той другий бік. Його завжди манить кожний другий берег» (Самчук, т. 1: 252). Володькові координати - невідомі береги. Він мріяв сіяти зерна істини, намагаючись заглянути за невідомі обрії.

У цьому й полягає конфлікт поколінь: часопросторова проєкція молодшого Довбенка підноситься вгору, він не може «заземлитись», обмежитись простором хутора й плодючої землі. I парубок, наче блудний син, покидає рідну домівку. А батько Матвій не знає, куди пішов його син і чи повернеться він коли-небудь: «Але Матвій не має права на це зважати. Його кличе земля, він мусить бути 3 нею» (Самчук, т. 2: 324). Отже, проблемою роману «Волинь» $\epsilon$ екзистенційний вибір сенсу життя, що відтворено письменником на прикладі зміни поколінь. Кожен із представників свого покоління робить вибір за велінням душі й серця, вибір індивідуального та національного простору у пошуках сенсу життя. Отже, трансцендентність сакрального може бути для людини лише глибинною мотивуючою силою; а результатом - конкретна, цілком предметна розташованість у певному просторі й часі. Екзистенція не може відірватися від профанного, бо це їі справжнє середовище.

Таким чином, феномен духовного (в сакральній сфері автентичного волинського макротопосу) стає специфічним модусом Самчукового художнього мислення (Плетенчук, 2011: 169), а вертикальна часопросторова проєкція 3 координатами підземелля - земля (родина) - небо є конструкцією світобудови, зв'язку мрії та ідеалу з реальністю, а отже, цілісності, а пізнання людиною світу та іiі потяг до невідомого розкриває сакральний простір через профанне. Саме це й дає змогу розглядати Самчукову 
«волинську сагу» як епічний сімейний наратив, що лише частково втратив міфологічну сакральність.

У книзі «Мистецтво роману та XX століття» Д.В. Затонський розподіляє романи на два основні види: «відцентровий», тобто монументальний, панорамний i «доцентровий», той, що тяжіє до відображення, переломлення, «розчеплення» життя якоюсь індивідуальною свідомістю, до ліричних, умовних, метафоричних форм (Затонський, 1972).

Саме таким «доцентровим» романом, на нашу думку, можна вважати сімейну хроніку «Марія» У. Самчука. У романі описано трагічні події Голодомору 1932-1933 років на території України. Доля Марії зображена на тлі суспільних колізій України радянських часів. Хроніка життя Марії (від народження до смерті) означена як книга життя та вказує на жанрову своєрідність твору - романхроніка. Слід зауважити, що, досліджуючи жанрові особливості сімейних романів, російський науковець Є. Нікольський наполягає на використанні терміна «сімейна хроніка» стосовно всіх жанрових моделей сімейних романів (Нікольський, 2009). Ми вважаємо, що роман «Марія» є класичним зразком сімейної хроніки XX століття, адже його побудова базується на лінійному принципі, що формує цілісне і об'єктивне сприйняття історичних явищ. Валерій Шевчук історію родини Марії та Корнія, їх батьків, дітей називає історією «“великого житія” роду живого» (Шевчук, 1992).

Сімейну хроніку «Марія» У. Самчука можна назвати «романом долі» (такий вид класифікації жанру роману пропонує дослідник I. Мегела) (Мегела, 2008). Як правило, у такому романі зображено життя людини з її проблемами. Цей вид роману має екзистенціальну проблематику i звернений до сучасності, у ньому конкретно визначені категорії часу і простору. Він являє собою діалог із часом i суспільством, апелює одночасно і до естетичного почуття, і ще в більшій мірі - до соціального досвіду. Можемо вважати такий тип сімейної хроніки відголоском прадавньої функції сімейного тексту, яка полягає в збереженні й трансляції важливої інформації про рід, типи взаємостосунків, тобто про панораму життя певного 
прошарку суспільства. «Розповідання тексту має на меті не тільки проінформувати, а показати й застерегти від певних негативних моментів, які відбулися» (Порохняк, 2009).

«Матерям, що загинули голодною смертю на Україні в роках 1932-1933», - таку присвяту робить сам автор, що є одним із виявів паратекстуальності, з допомогою яких «автор відкриває зовнішню межу тексту для інтертекстуальних зв’язків і літературно-мовних віянь різних напрямків та епох, тим самим наповнюючи і розкриваючи внутрішній світ тексту» (Фатєєва, 1998: 32).

В основі психологізму в літературі, як уже було зазначено вище, лежить вертикаль (явно або дискретно). Усі злети й падіння, страждання й досягнення людського духу відображені так чи інакше в символіці вертикалі. Із вертикаллю завжди пов'язане розуміння життя і смерті (фізичної і духовної), пошуки сенсу земного буття, призначення людини, утвердження життєвих цінностей і розвінчання псевдоцінностей, прагнення щастя (Копистянська, 2012: 119).

На тлі часопросторової вертикалі в романі «Марія», як у давніх чи Біблійних міфах і легендах, постає боротьба між Добром і Злом. Саме таку установку робить автор уже в перших рядках твору: «У неї чоло, а за ним хорониться брунька розуму, яка от-от розів'ється, розцвіте й пізнає добро і зло» (Самчук, 1991: 5-6). Кожен з героїв твору опиняється на межі цієї боротьби. Символом добробуту й щастя, як і в романі «Волинь», постає людська праця: «Сонце весь час працювало» (Самчук, 1991: 6). Сонце, як сакральний символ вищого, небесного, є гарантією існування всього живого на Землі. Людина, так само як і сонце, повинна весь час працювати. Це основа ii добробуту, щастя, родинного життя. Праця приносила насолоду Марії: «Та що Марії праця? Жне, в’яже за косарями i, мов дзвінок, гомонить...» (Самчук, 1991:12). Праця наповнювала сенсом іiі життя. Щастя Марія вбачала в злагоді й добробуті, але шлюб без кохання став для жінки розчаруванням і злом. Основою щасливого шлюбу $є$ взаємність, а вона Гната не любила. Сподівалася втішити душевний смуток любов’ю до праці й щастям материнства: «...Втіху мала, 
коли почувала вагітність. Тепер хоч не буде сама... Марія тішилась $\mathrm{i}$ працювала...» (Самчук, 1991: 41).

Смерть, морок, темрява постають у романі символом суцільного Зла, що затьмарює людині сонце. Це зло спустошує душу Марії. Спочатку морок і темрява забирають найрідніших людей - батька й матір. А потім великим горем для жінки стала смерть дітей. Марія відвертається від праці, обирає шлях гріха. Марія загуляла, «повернулася в далекі царства минулого дівоцтва» (Самчук, 1991: 52). Адже вона щиро кохає Корнія, який повернувся з арміі. Та цей вчинок став великим злом стосовно Гната, який кохав Марію до нестями: чоловік дізнався, що Марія знову зустрічається з Корнієм. На Гната, хворого й немічного, одразу подивилося Зло, а «сонце почорніло, як підбите око» (Самчук, 1991: 63). Темрява наповнює душу Гната, і він прагне помсти, тим самим опиняючись на боці Зла: урешті-решт, до самозречення закоханий чоловік спалює хату Марії.

Плодом людської праці, ознакою добробуту української родини в романі «Марія» є хліб - символ сакрального й профанного. Але суспільне Зло, тоталітарна машина, насувається на селян і знищує мільйони українських родин. «Крицевими дорогами мчать у далечінь поїзди. Там сніги, морози. Там сосни шумлять і виють білі ведмеді. Соловки. Страшне, незабутнє слово, страховище і рана віків. Мільйонна могила України» (Самчук, 1991: 141). У тих, хто залишився в Україні, відбирають хліб: вони приречені на голодне співіснування та втрачають почуття милосердя, взаємодопомоги та співчуття. «Хліб. Виривали один другому з рук, з зубів... Сухі, жилаві руки простягалися за відібраною торбою, а з розтрощеного черепа лилася жовта кров» (Самчук, 1991: 128).

Типовим представником тоталітарної системи, уособленням суспільного зла у творі є Максим Перепутько, середній син Марії. Корній бачить у ньому себе, «темний» бік своєї душі, і розуміє, що Максим - запроданець Пекла. Корній мудро, по-філософськи узагальнює: «Немає тепер злодіїв. Його замінив грабіжник, якому нема заборон...» (Самчук, 1991: 132) Корній вирішує вбити синавиродка, бо відчуває відповідальність за життя тих людей, яких 
140 Наукові записки ХНПУ ім. Г.С. Сковороди. Літературознавство, 2020, вип. 2(96)

Максим щодня знищує, адже сучасне завжди віддзеркалюється як у минулому, так і в майбутньому.

Образ Марії - символ материнської жертовності й доброти, прообраз Біблійної Марії, яка ладна йти за своїми дітьми на Голгофу. Гнат так подумки і звертається до неї, порівнюючи з Божою Матір'ю: «Маріє! Встань. Згадай велику Матір, яка стояла під хрестом розп'ятого Сина і чекала Його смерті» (Самчук, 1991: 107)

У романі втілена ідея євангельського воскресіння. Смерть Марії $\epsilon$ початком неодмінного відродження. Вона $є$ необхідним моментом переоцінки пережитого, найважливішою умовою доступу до іншого рівня буття. Смерть - це і є момент істини, після якого обов'язково буде відродження. Вона констатує перехід у підземелля, але із землі завжди народжується щось нове. У філософському розумінні людина звільняється від умовностей і набуває цілковитої свободи.

На нашу думку, у романі «Марія» увиразненою стає не тільки філософська часопросторова вертикаль, а й вертикаль соціальна, бо «загальна проблематика твору Уласа Самчука $є$ типологічно розмаїтою-від психологічної (рефлексіялюдської душі) до соціальної (доля людини національної (доля нації) і навіть філософської (i долю людини, і долю нації подано під соціокультурним, історіософським поглядами). Візія національної держави постає як новий міф, орієнтований, за У. Самчуком, на концепцію новоїлюдини» (Гаєвська, Линченко, 2009). Ідеалам, символам добра й милосердя У. Самчук протиставляє зло - байдужість і руйнацію, утворюючи таким чином опозиційні пари. У такий спосіб в У. Самчука відбувається реалізація дихотомічної моделі свій/чужий (свій/ворог), притаманної літописній літературі (Гаєвська, Линченко, 2009).

\section{Висновки}

Сакральні символи сімейних романів У. Самчука нерозривно поєднані із символами профанними. Дві життєві орієнтації, два способи життя надають протилежного смислу діянням людини у світі. Ці дві орієнтації умовно позначаються поняттями «сакральне» i «профанне», що дають можливість сконцентрувати смислові 
відтінки антитетичних пар стосовно екзистенціального досвіду: духовне - земне, душа - плоть, тлін - вічність. Рефлексія стосовно власного існування вже ставить людину в ситуацію пошуку, оскільки вона передусім відкриває себе у світі як річ серед інших речей (тлін і плоть) і в цій перспективі їй вимальовується смерть і страх потрапити у царство підземне. Рятуючись від розкладу й руйнації, людина мусить шукати іншого життя. Сдиною альтернативою може бути сакральне. А гамлетівська та фаустівська парадигми як вияв інтертекстуальності у творах У. Самчука прив' язані до національного українського грунту (Гаєвська, Линченко, 2009), тому жанровостильові особливості його романів «Волинь» і «Марія» вирізняються не лише самобутнім потрактуванням проблем родової пам'яті, безсмертя, сутності життя, а й матрицею сакральних і профанних архетипних символів, що утворюють своєрідну філософську художньо-смислову канву Самчукових творів.

\section{Література}

Барт, Р. (1989). Избранные работы: Семиотика: Поэтика. Москва: Прогресс.

Гаєвська, Н. Линченко, М. (2009). Добро і зло в романі Уласа Самчука «Марія». Наукові записки, 85, 123-129.

Данилевич, М. (2000). Украӥнський образ світу у трилогії У. Самчука «Волинь». Тернопіль: ТДПУ.

Джиоева, А. (2019). Традииии семейного романа в отечественной прозе XX столетия. Автореф. дис. канд. філол. наук. Москва. Режим доступу https:/www.dissercat.com/content/ traditsii-semeinogo-romana-v-otechestvennoi- proze-khkh-stoletiya.

Элиаде, М. (1999). Избранные сочинения: Очерки сравнительного религиоведения. Москва: Ладомир.

Женетт, Ж. (1998). Фигурыл:в 2-x m. Т.1: Палимпсесты. Литература во второй степени. Москва: Изд-во им. Сабашниковых.

Затонский, Д.В.(1972). Искусство романа и ХХ век. Москва: Художественная литература. 
142 Наукові записки ХНПУ ім. Г.С. Сковороди. Літературознавство, 2020, вип. 2(96)

Ильин, И.П. (1999). Интертекстуальность. Современное литературоведение (страны Западной Европы и США): концепты, иколь, терминыл. Москва: INTRADA. 204-210.

Кристева, Ю. (2000). Бахтин, слово, диалог и роман. Французская семиотика: От структурализма к постструктурализму. Москва: ИГ Прогрес. 427-457.

Кононенко, В. (1991). Словесні символи в семантичній структурі фраземи. Мовознавство. 6, 30-36.

Копситянська, Н. (2012). Час і простір у мистеитві художнього слова. Львів: ПАІС.

Лотман, Ю. (1970). Структура художественного текста. Москва: Искусство.

Мегела, I. (2008). Угорський роман 20-30 років ХХ століття. Проблематика. Жанрова структура. Форма оповіді. Київ: Видавець Карпенко В.M.

Никольський, Е. (2009). К вопросу о специфике жанра - семейной хроники и его зарождении в русской классической литературе. Вопрос языка и литературы в современных исследованиях: КириллоМефодиевские чтения. Москва.

Плетенчук, Н. (2011). Художній феномен сакралізації волинського макротопоса в прозі Уласа Самчука. Питання літературознавства. 83. $163-171$.

Порохняк, Н. (2009). Роман сімейна-хроніка та сімейний наратив. Волинь філологічна: текст і контекст. 222-230.

Самчук, У. (1993). Волинь: Роман: у 3 ч. Т.1: Куди тече та річка. К.: Дніпро. Самчук, У. (1993). Волинь: Роман: у 3 ч. Т.1: Війна і революція. К.: Дніпро. Фатеева, Н. (1998). Типология интертекстуальных элементов и связей в художественной речи. Изв. АН: сер. “Литературы и языки”. 5, 25-38.

Шевчук, В. (1992). Улас Самчук та його волинська сага. Украӥнська мова $i$ література в школі. 11-12, 30-32.

\section{References}

Bart, R. (1989). Yzbrannye raboty: Semyotyka: Poetyka. Moskva: Prohress. [In Russian]. 
Hayevs'ka, N, Lynchenko, M. (2009). Dobro i zlo v romani Ulasa Samchuka «Mariya». Naukovi zapysky. 85, 123-129. [In Ukrainian].

Danylevych, M. (2000). Ukrayins'kyy obraz svitu u trylohiyi U. Samchuka «Volyn'». Ternopil': TDPU. [In Ukrainian].

Dzhyoeva, A.(2019) Tradytsyy semeynoho romana $v$ otechestvennoy proze XX stoletyya. Avtoref. dys. kand. filol. nauk. Moskva. Retrieved from https://www.dissercat.com/content/traditsii-semeinogo-romana-votechestvennoi-proze-khkh-stoletiya_[In Russian].

Eliade, M. (1999). Izbrannyye sochineniya: Ocherki sravnitel'nogo religiovedeniya. Moskva: Ladomir. [In Russian].

Zhenett, ZH. (1998). Figury:v 2-kh t. Vol.1: Palimpsesty. Literatura vo vtoroy stepeni. Moskva: Izd-vo im. Sabashnikovykh [In Russian].

Zatons'kiy, D.V. (1972). Iskusstvo romana i XXvek. Moskva: Khudozhestvennaya literatura. [In Russian].

Il'in, I.P. (1999). Intertekstual'nost'. Sovremennoye literaturovedeniye (strany Zapadnoy Yevropy i SSHA): kontsepty, shkoly, terminy. Moskva: INTRADA. 204-210 [In Russian].

Kristeva, Yu. (2000). Bakhtin, slovo, dialog i roman. Frantsuzskaya semiotika: Ot strukturalizma k poststrukturalizmu. Moskva: IG Progres. 427-457. [In Russian].

Kononenko, V. (1991). Slovesni symvoly v semantychniy strukturi frazemy. Movoznavstvo 6, 30-36. [In Ukrainian].

Kopsytyans'ka, N. (2012). Chas i prostir u mystetstvi khudozhn'oho slova. L'viv: PAIS. [In Ukrainian].

Lotman, Yu. (1970). Struktura khudozhestvennogo teksta. Moskva: Iskusstvo [In Russian].

Mehela, I. (2008). Uhors'kyy roman 20-30 rokiv XX stolittya. Problematyka. Zhanrova struktura. Forma opovidi. Kyiv: Vydavets' Karpenko V.M. [In Ukrainian].

Nikol's'kiy, Ye. (2009). K voprosu o spetsifike zhanra - semeynoy khroniki i yego zarozhdenii $\mathrm{v}$ russkoy klassicheskoy literature. Vopros yazyka $i$ literatury v sovremennykh issledovaniyakh: Kirillo-Mefodiyevskiye chteniya. Moskva. [In Russian]. 
144 Наукові записки ХНПУ ім. Г.С. Сковороди. Літературознавство, 2020, вип. 2(96)

Pletenchuk, N. (2011). Khudozhniy fenomen sakralizatsiyi volyns'koho makrotoposa v prozi Ulasa Samchuka. Pytannya literaturoznavstva. 83. 163-171. [In Ukrainian].

Porokhnyak, N. (2009). Roman simeyna-khronika ta simeynyy naratyv. Volyn' filolohichna: tekst i kontekst. 222-230. [In Ukrainian].

Samchuk, U. (1993). Volyn': Roman: $u 3$ ch. Vol.1: Kudy teche ta richka. Kyiv: Dnipro. [In Ukrainian].

Samchuk, U. (1993). Volyn': Roman: $u 3$ ch. T.1: Viyna i revolyutsiya. Kyiv: Dnipro. [In Ukrainian].

Fateyeva, N. (1998). Tipologiya intertekstual'nykh elementov $i$ svyazey $v$ khudozhestvennoy rechi. Izv. AN: "Literatury i yazyki” 5, 25-38. [In Russian].

Shevchuk, V. (1992). Ulas Samchuk ta yoho volyns'ka saha. Ukrayins'ka mova $i$ literatura $v$ shkoli. 11-12, 30-32. [In Ukrainian].

\section{Анотація}

O.O. Румянцева-Лахтіна. Інтертекстуальний контекст символіки сімейних романів Уласа Самчука крізь призму філософської часопросторової вертикалі

У статті здійснено спробу виявити жанрово-стильові домінанти сімейної саги «Волинь» і сімейної хроніки «Марія» У. Самчука як субжанрів сімейного роману в українській літературі початку $\mathrm{XX}$ століття, дослідити образність, поетику та сакральні образи-символи, які є каталізаторами зображувальної епохи, з'ясувати особливості символіки онтологічних, антропологічних та профанних «кодів» сімейних романів крізь призму інтертекстуальності та філософського й соціального розуміння часопросторової вертикалі художнього твору. Розглянуто романи «Волинь» $\mathrm{i}$ «Марія» У. Самчука як варіації реалізації універсальної моделі розповіді про сакральні духовні цінності, про родовід, про добро і зло крізь призму інтертекстуальності, а саме через інтерпретацію образів-символів, репрезентованих письменником.

Для дослідження застосовано методологією інтертекстуальності та інтертексту за концепцією французького структураліста й постструктураліста Ролана Барта, який теоретично обгрунтував поняття «твір» та «текст» за принципом «читання-письма». 
Визначено, що сакральні символи сімейних романів У. Самчука (небо, сонце, земля, добро і зло) нерозривно поєднані із символами профанними (людська праця, хліб, будинок, родина). Дві життєві орієнтації, два способи життя надають протилежного смислу діянням людини у світі. Ці дві орієнтації умовно позначаються поняттями «сакральне» і «профанне»: духовне - земне, душа - плоть, тлін - вічність. Рефлексія стосовно власного існування створює для героїв У. Самчука ситуацію пошуку сенсу життя, оскільки перед кожним із них завжди постає проблема екзистенційного вибору.

Зроблено висновок, що жанрово-стильові особливості сімейних романів «Волинь» і «Марія» вирізняються не лише самобутнім потрактуванням проблем родової пам'яті, безсмертя, сутності життя, а й матрицею сакральних і профанних архетипних символів, що утворюють своєрідну філософську художньо-смислову канву творів У. Самчука.

Ключові слова: сімейна сага, сімейна хроніка, сакральне, профанне, часопросторова філософська вертикаль, інтертекстуальність.

\section{Аннотация \\ О.А. Румянцева-Лахтина. Интертекстуальный контекст символики семейных романов Уласа Самчука сквозь призму временно-пространственной философской вертикали}

В статье предпринята попытка выявить жанрово-стилистические доминанты семейной саги «Волынь» и семейной хроники «Мария» У. Самчука как субжанров семейного романа в украинской литературе начала XX века, исследовать образность, поэтику и сакральные образысимволы, которые являются катализаторами изображаемой эпохи, выяснить особенности символики онтологических, антропологических и профанных «кодов» семейных романов сквозь призму интертекстуальности, философского и социального понимания временно-пространственной вертикали художественного произведения. Романы «Волынь» и «Мария» У. Самчука рассмотрено как вариации реализации универсальной модели рассказа о сакральных духовных ценностях, о родословной, о добре и зле сквозь призму интертекстуальности, а именно через интерпретацию образов-символов, представленных писателем. 
146 Наукові записки ХНПУ ім. Г.С. Сковороди. Літературознавство, 2020, вип. 2(96)

Для исследования применена методология интертекстуальности и интертекста по концепции французского структуралиста и постструктуралиста Ролана Барта, который теоретически обосновал понятие «произведение» и «текст» по принципу «чтения-письма».

Определено, что сакральные символы семейных романов У. Самчука (небо, солнце, земля, добро и зло) неразрывно связаны с символами профанными (человеческий труд, хлеб, дом, семья). Две жизненные ориентации, два образа жизни предоставляют противоположный смысл деяниям человека в мире. Эти две ориентации условно обозначаются понятиями «сакральное» и «профанное»: духовное - земное, душа - плоть, тлен - вечность. Рефлексия относительно собственного существования создает для героев У. Самчука ситуацию поиска смысла жизни, поскольку перед каждым из них всегда возникает проблема экзистенциального выбора.

Сделан вывод, что жанрово-стилистические особенности семейных романов «Волынь» и «Мария» отличаются не только оригинальной трактовкой проблем родовой памяти, бессмертия, жизненного бытия, но и матрицей сакральных и профанных архетипных символов, образующих самобытную философскую художественно-смысловую канву произведений У. Самчука.

Ключевые слова: семейная сага, семейная хроника, сакральное, профанное, временно-пространственная философская вертикаль, интертекстуальность.

\section{Abstract \\ O. Rumiantseva-Lakhtina. The Intertextual Context of the Symbols of Ulas Samchuk's Family Novels through the Prism of the Temporal-Spatial Philosophical Vertical}

The article attempts to highlight the genre and stylistic dominants of the family saga "Volyn" and the family chronicle of U. Samchuk "Maria" as subgenres of the family novel in the Ukrainian literature of the early 20th century, to investigate imagery, poetics and sacred images-symbols that are catalysts of the depicted era, to reveal features of the symbolism of ontological, anthropological and profane "codes" of family novels through the prism of intertextuality, philosophical and social understanding of the space-time vertical of a literary work. The novels "Volhynia" and "Maria" by U. Samchuk are considered as variations of 
the implementation of the universal model of the story about sacred spiritual values, about genealogy, about good and evil through the prism of intertextuality, namely through the interpretation of images-symbols presented by the writer.

The study uses the methodology of intertextuality and intertext according to the concept of the French structuralist and post-structuralist Roland Barthes, who theoretically substantiated the concept of "work" and "text" on the principle of "reading-writing".

It has been determined that the sacred symbols of U. Samchuk's family novels (heaven, sun, earth, good and evil) are inextricably linked with the symbols of the profane (human labor, bread, home, family). Two life orientations, two ways of life provide the opposite meaning to a person's actions in the world. These two orientations are conventionally designated by the concepts of "sacred" and "profane": spiritual - earthly, soul - flesh, decay - eternity. Reflection on their own existence creates a situation for U. Samchuk's heroes of searching for the meaning of life, since each of them always faces the problem of existential choice.

It is concluded that the genre and stylistic features of the family novels "Volyn" and "Maria" differ not only in the original interpretation of the problems of ancestral memory, immortality, life, but also in the matrix of sacred and profane archetypal symbols that form the original philosophical artistic and semantic canvas of U. Samchuk.

Key words: family saga, family chronicle, sacred, profane, temporal-spatial philosophical vertical, intertextuality.

Рукопис статті отримано 16 жовтня 2020

Рукопис затверджено до публікачії 3 грудня 2020

\section{Інформація про автора}

Румянцева-Лахтіна Оксана Олександрівна - здобувачка ступеня доктора філософії кафедри української літератури та журналістики імені професора Леоніда Ушкалова Харківського національного педагогічного університету імені Г.С. Сковороди, вул. Валентинівська, 2, м. Харків, 61168, Україна; e-mail: roksik2911@gmail.com; https://orcid.org/0000-0001-7588-3395. 